\title{
The God's Grand Costume Ball: a Classic Maya prophecy for the close of the thirteenth Bak'tun
}

\author{
Barbara MacLeod \\ Independent Scholar, Austin, Texas, USA \\ email: bmacleod@austin.rr.com
}

\begin{abstract}
In the favored correlation between the Mayan and Gregorian calendars, a time period of a little over 5125 solar years will be completed on the winter solstice of 2012. While numerous Classic Maya hieroglyphic texts feature the previous closing of this era in 3114 BCE, only one text-Monument Six of Tortuguero, Tabasco, Mexico-mentions the future event. The portion of the monument describing the event is damaged, and previous attempts to decipher this part of the text have been inconclusive. These have inadvertently led to popular and farflung millenniarian speculations about ancient esoteric knowledge. The whole of Tortuguero Monument Six - an exquisite piece of Classic sculpture and literature - addresses the fundamental relationship between royal charter, warfare, captive sacrifice, appeasement of the gods, the ordering of time, and the stability of society for posterity. The author and her colleaguesemploying high-resolution photos and great attention to script detail- have brought to light a more accurate interpretation of the damaged text. The results of this effort suggest a distant future ceremony of investiture for a deity of deep-time transitions whose reflexes can be seen in indigenous community celebrations of highland Guatemala.
\end{abstract}

Keywords. Maya Long Count, thirteenth Pik, 2012, Tortuguero Monument Six, Bolon Yokte', Rilaj Mam

\section{Introduction}

A limestone wall panel known as Monument Six (Figs 1 \& 2) from the Classic Maya site of Tortuguero, Tabasco, Mexico has attracted global attention in New Age circles because it records the Maya calendar date that falls on December 21, 2012. Of the thousands of ancient Maya texts known to us, this is the only one that documents the upcoming close of the thirteenth pik. The Classic Ch'olan word $p i k$ will be employed for this time period of 144,000 days, thirteen of which will have elapsed on this day, counting from the Creation Day of August 11, 3114, BC.

\section{The site of Tortuguero}

Tortuguero lies at the foot of an escarpment called Gavilán Blanco, at the northern edge of the Chiapas highlands, which overlooks a vast fertile plain threaded with lagoons and navigable rivers connecting to the Gulf of Mexico. Only a few small projects have been undertaken at Tortuguero. For decades, the limestone cliffs and structures have been harvested for building material, leaving little visible on the surface. A cement factory has long operated a quarry at the site, and the destruction has been severe.

The known hieroglyphic texts (Mathews 1975; Riese 1978; 1980; Gronemeyer 2004; 2006; Arellano Hernández 2006; Gronemeyer \& MacLeod 2010) are located on nine monuments and a fragment, a piece of jade and a wooden box. Most of these were fashioned 


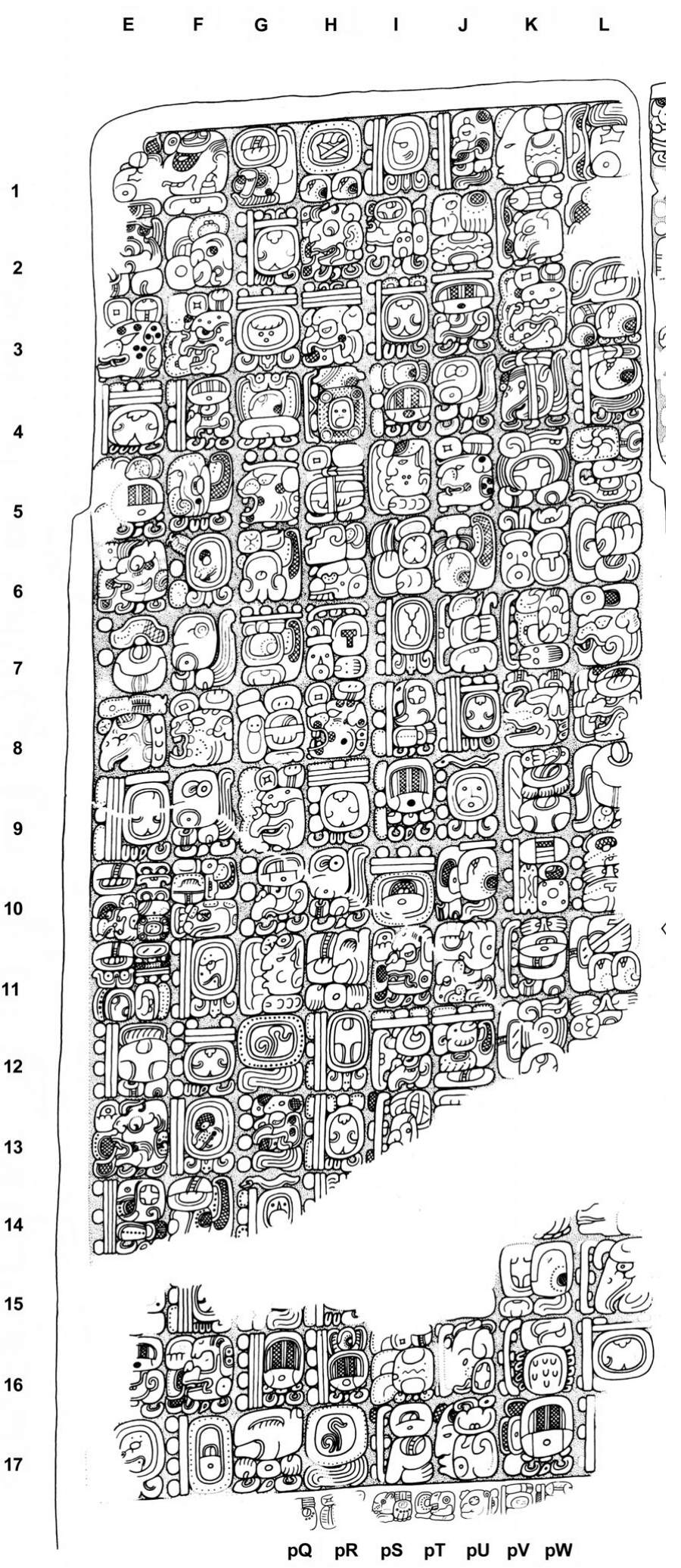

Figure 1. The main text of Tortuguero Monument Six. Drawing: Ian Graham. 


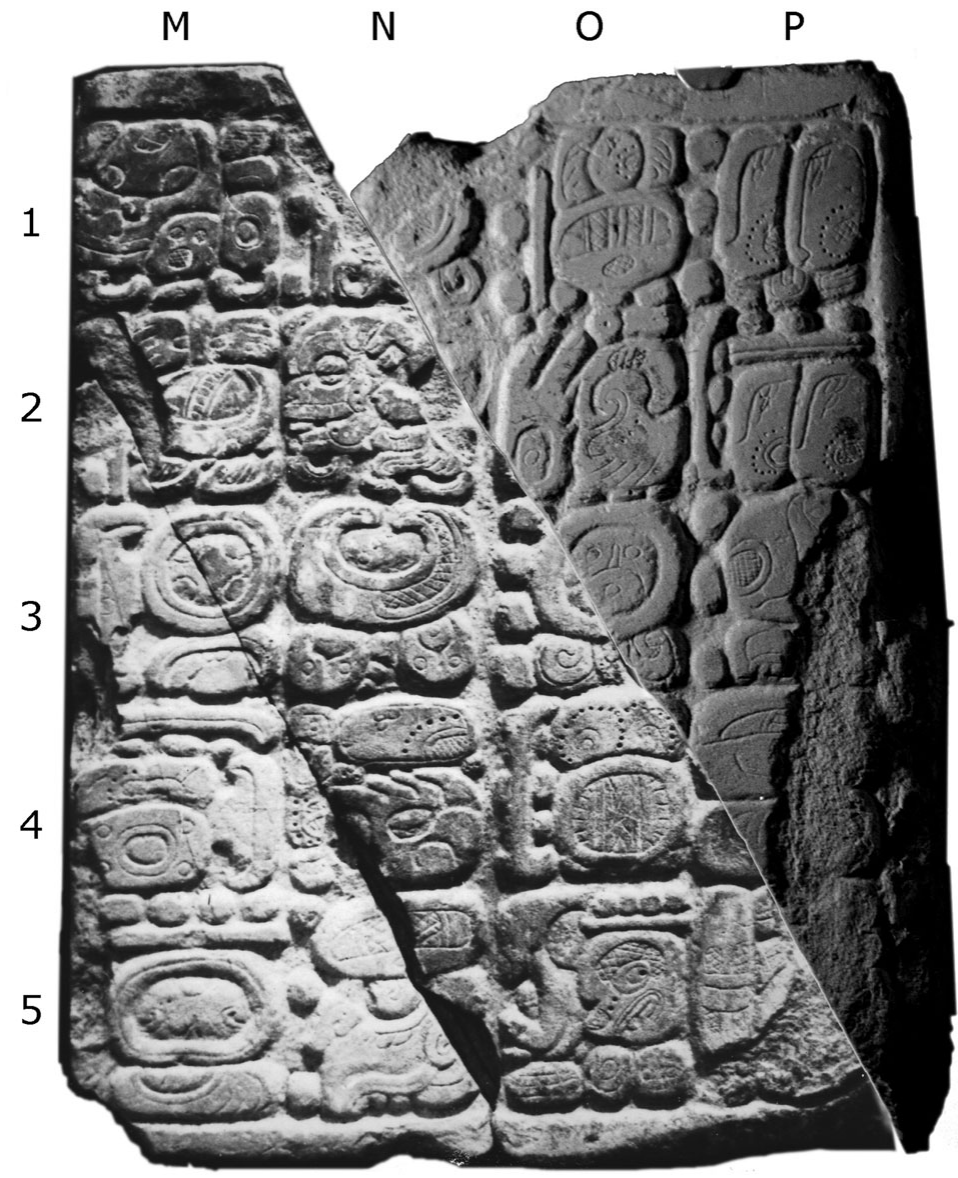

Figure 2. The right flange of Tortuguero Monument Six. Photo: Paul Johnson \& Mark Van Stone.

during the rule of a famous king named Bahlam Ajaw or 'Jaguar Lord', who was born in $612 \mathrm{AD}$, acceded to the throne at age 32 , undertook military campaigns, and honored his predecessors, parents, lineage ancestors, patron gods and the gods of time with ceremony and with the blood of war captives. He married twice and fathered an heir, dedicated an important building where Monument Six was likely installed, and from that datum counted back to the foundation ritual of the building 300 years prior, and forward to the 13.0.0.0.0 date. His death date in $679 \mathrm{AD}$ at age 67 appears on the wooden box; his birth date, likely carved on the missing left flange of Monument Six, is only known to within five days owing to a broken days-unit coefficient in a retrospective count. He ruled for 35 years. Much of his known history appears on Monument Six.

The formerly T-shaped monument was found as a capstone on a burial in 1958. It is not known why it was placed there in antiquity, nor how or when it was broken. Much of it is on display at the regional anthropology museum in Villahermosa, Mexico. It stands just over six feet tall. One fragment of the main text resides in a museum in New York, and two fragments of the right flange are in an unknown private collection, but were photographed by Donald Hales (pers. comm. 2009) before they disappeared. The left flange which recorded the king's birth has never been seen. The right flange (Fig. 2 ), broken into three pieces, has a spalled-off corner, leaving the content of two critical glyph blocks problematic. 


\section{Decipherment of a critical eroded sign}

Even more daunting had been a single syllable upon which, it appears, galactic destiny teeters. This is the suffix under a hand sign (Fig. 2, O5a) whose syllabic /ye/ value signals a possessed noun based on a root beginning with /e/. An epigraphic study by Houston \& Stuart (1996) included a speculation, subsequently withdrawn, that this root might be /'eem/ meaning 'to descend', translated in context as 'his descent'. This event is followed at O5b by the name of the god Bolon Yokte', a god of war whom we have met at the Creation in the court of God L. The meaning of his name is elusive, though it can be analyzed as 'nine wooden basal supports' or 'nine feet of wood'. In the Yucatec Maya language, the cognate /okom che'/ is 'wooden column' or 'house post'. I suspect his name is a metaphor for a ninefold deity or underworld pantheon which 'supports' the architecture of war and sacrifice in a reciprocal relationship with the forces of regeneration and rebirth. He has centipede and chthonic solar attributes.

\section{A metaphysical millenarian interpretation}

Carl Johan Calleman is a leading proponent of the '2012 movement'. He prophesies an evolutionary transformation culminating in the descent of nine galactic energy waves accelerating to fulfill a Shift of the Ages. He credits the Maya with having foretold it, and himself with unlocking its mysteries. He says:

"I assumed that the significant Mayan pyramids had been built in nine steps because they were symbolic of nine levels of creation. ... I then found that with such a model an enormous amount of historical facts started to make sense if they were seen as results of cosmic energy shifts. This however could be seen to be true only if the nine levels all ended at the same time... It thus seemed obvious that the understanding of such energy shifts must have been the basis of the prophetic tradition of the Maya." (Calleman 2010)

Then he discovered the aforementioned 1996 'descent' proposal for Tortuguero Six. He goes on:

"The verification from the Tortuguero monument that the ancient Maya looked upon the end of creation as the simultaneous descent of Nine different deities, or manifestation of nine cosmic forces, is ... very timely as we are now on the eighth level of evolution and soon about to climb up one step to the ninth level, the Universal Underworld. That ... nine cosmic forces will descend and manifest simultaneously at the end date is thus no longer an unorthodox idea, but instead the only meaningful explanation that can be given to Tortuguero Monument 6." (ibid.)

\section{A more likely interpretation}

A new understanding of the 13 pik event (Gronemeyer \& MacLeod, 2010)-involving several epigraphers and employing a new mosaic photograph by Mark Van Stone and Paul Johnson (Van Stone 2010) — was reached in the summer of 2010. In it we propose that the problematic syllable cannot be a / ma/ - thus cannot help spell a word meaning 'descent'-but is rather a /ni/, yielding an antipassive verb stem /yeen/ meaning both 'a display' and 'adornments'. Because we now had a key with which to unlock the syntax and reconstruct the damaged signs, we proceeded to decipher the full statement (Fig. 2, M5-P5):

cha' k'i:n, bolon winikij, u:x ha'ab, waxak winikha'ab, u:x pik, tzuhtzjo:m uyu:xlaju:n pik Chan Ajaw, U:x Uni:w.

uhto:m il ye:n Bolon Yokte' ta chak joyaj.

two days, nine-score days, three Tun, eight K'atun and three Pik (forward), it will be completed the thirteenth Pik; it will be 4 Ajaw, $3 \mathrm{~K}^{\prime}$ ank'in.

it will happen; the witnessing of the adornments of Bolon Yokte' in the great investiture. 
The verbal noun /joyaj/ at P5 is known from the hieroglyphic corpus to refer to a king's accession to the throne, but it has been ambiguous. In relevant languages the root /joy/ means several things: 'to wrap', 'to encircle', 'to enclose' and 'to move in a circular procession'. We settled on the translation 'investiture' after examining every scene in the corpus associated with this verb and narrowing the field to donning vestments, often in rites of accession. But the other possibility - that of a procession - should be considered as well. Also helpful were pottery scenes in which a lord is shown putting on a costume and preening while attendants hold mirrors and other items of dress. Here the translation 'dressing' is best.

\section{Who is Bolon Yokte'?}

A god of war is to be invested: he will be arrayed and paraded in his finery and insignia and will be granted dominion over the close of thirteen piks. One could say that Bahlam Ajaw — via his wars and offerings of sacrificial blood-has spent his entire reign negotiating with this god in order to honor his ancestors and secure the continuation of his bloodline in perpetuity. In return, Monument Six tells us, his lineage's repository of divine power is filled to overflowing (Fig. 1, G7-G9).

What else do we know of Bolon Yokte'? We know that he was in attendance on the Creation day as one of the gods set in order, with old cigar-puffing, jaguar-robed God L presiding (Carlson, this volume). Boot (n.d.) has proposed that Bolon Yokte' appears on both the 'Vase of the Seven Gods' and the 'Vase of the Eleven Gods' with facial features of the Sun God and a centipede headdress, suggesting his connection to another war deity and avatar of the Underworld Sun-Huk Chapat Tz'ikin K'inich Ajaw or 'Seven Centipede Eagle, the Sun Lord'.

A recent study by Eberl \& Prager (2005) shows that rulers may impersonate Bolon Yokte', displaying his signature flint spear point enclosed by centipede jaws, or a carrying bag or diadem of the war god Tlaloc, or a shield bearing the face of the Jaguar God of the Underworld, and a rope around the neck. An image from the Postclassic Dresden Codex demonstrates that Bolon Yokte' is a god of destruction (see Callaway, this volume). He is named in nearby texts as 'lord of the underworld' and in connection with war and 'the end of days', while he and a doppelganger attack God N, another underworld potentate and a quadripartite being who holds up the corners of the sky. Both attackers have weapons and a rope around the neck.

Many of these motifs congregate in the central image of the Tablet of the Sun at Palenque - a city with which Bahlam Ajaw's dynasty was once allied. This panel constellates the obligation to conduct war as a complement to agricultural fertility and lineage power. Here I suggest that the gods seen crouching at the base of this war constellation are functioning as its /okte'/ or basal supports; one is God L and another, the deified essence of regenerative bones and the maize plant. The title /okte'/ is employed by human protagonists several times in the texts of this building. The Jaguar God of the Underworld - a solar deity - may also be an aspect of Bolon Yokte'.

An exquisite polychrome vessel known as the Regal Rabbit Vase shows a naked and shamed God L being taunted with obscenities by an imperious rabbit who has seized the robes, staff, and owl hat of the disempowered god, and who affirms in the text the collusion of Bolon Yokte' in the theft. In the other scene on the vase, we see God L appealing to the dismissive Underworld Sun God, who wears a stylized centipede headdress. A study by Zender \& Guenter (2003) proposes that God L and the Underworld Sun are eternally opposed, with God L ruling the nether regions during the day and being deposed at night by the Sun God. Boot (n.d.) now has evidence that the Sun God 
on the Regal Rabbit Vase is Bolon Yokte'. On a vase in a private collection one sees an Underworld Sun God named in the same text as Seven Centipede Eagle Sun Lord and Bolon Yokte'. The deity has the requisite sun god facial features - crossed eye, Roman nose, a single tooth - and in addition, a centipede topknot and a jaguar cummerbund.

\section{Easter celebrations of the Rilaj Mam in Santiago Atitlán, Guatemala}

We can turn now to modern-day parallels proposed in a recent article by Grofe (2009), following ethnographic work by Christenson (2001; pers. comm. 2011) in the town of Santiago Atitlán, Guatemala. The veneration of the Mam or Maximón occurs in a number of indigenous Guatemalan highland towns, but the celebrations of Santiago Atitlán are rich with antiquity and detail. The system of cofradías or religious brotherhoods was established in the sixteenth century by the Catholic Church to indoctrinate the population in the veneration of its saints, but the pre-conquest pantheon endured beneath the surface and was grafted onto the cofradías. A deity known as Rilaj Mam-or 'Ancient Grandfather' - arose within one of the cofradías to a prominence shared only by Christ and San Martín. San Martín's harvest festival, secret sacrificial deer dance and resurrection bespeak a reflex of the Classic Maize God. But where did the Ancient Grandfather come from?

To the people of Santiago Atitlán who revere the Rilaj Mam and petition him for wealth, fortune in love, and protection from witchcraft and from enemies, his origin is unknown, but he is said to be 'older than Christ'. His effigy has a frame of palo de pito, the tree which yields the red coral beans used for divination. Only his most intimate attendants have seen this frame. The bulk of his body is formed by the careful wrapping of many layers of clothing - a mix of traditional Atiteco weaving and ladino garb. At the start of Holy Week before Easter, the Mam's clothes are washed at midnight at the shore of Lake Atitlán, and the following midnight, behind a large woven mat in a completely dark room, he is dressed publicly by his attendants - though no-one can see him-in a recreation of the primordial world before the sun appeared. Thus, according to Christenson (pers. comm. 2011), the Mam is a pre-creation creation. He is never without attendants, and they surround him in droves during Semana Santa, offering him drinks and smokes and music while the townspeople petition him with money, candles, cigarettes and liquor (Fig. 3). At this time of the sacrifice of Christ, the Rilaj Mam symbolizes death and the underworld without being perceived as evil, even as he carries for some the projection of Judas Iscariot. His presence invokes the balance between life and death; without the sacrifice, there is no resurrection.

On Holy Wednesday, the Mam is carried through the town in a procession along with baskets of festive adornments and fruit, and is settled into the Mayor's office for several hours surrounded by his own guards in a symbolic dissolution of municipal authority. He also has a reputation as a womanizer who, in times past, got all the young women pregnant. In remembrance of his prowess, he lies with young women and decorated baskets of fruit while usurping the Mayor's role. Then he is carried in another triumphant procession to his shrine in the main plaza near the church where he is tied in his tree until Holy Friday. The rope with which he will be suspended by the neck is so potent that it is borne solemnly by a high-ranking priest both to and from his shrine. Finally, with the Easter resurrection of Christ, the Mam is defeated, and after joining in the procession of Christ's coffin, he and his attendants bow out and he is taken quickly back to the cofradía.

As Christenson and Grofe have proposed, the Rilaj Mam or Maximón is a reflex of an ancient, powerful, chthonic deity. Both God L and Bolon Yokte' are candidates, and they 


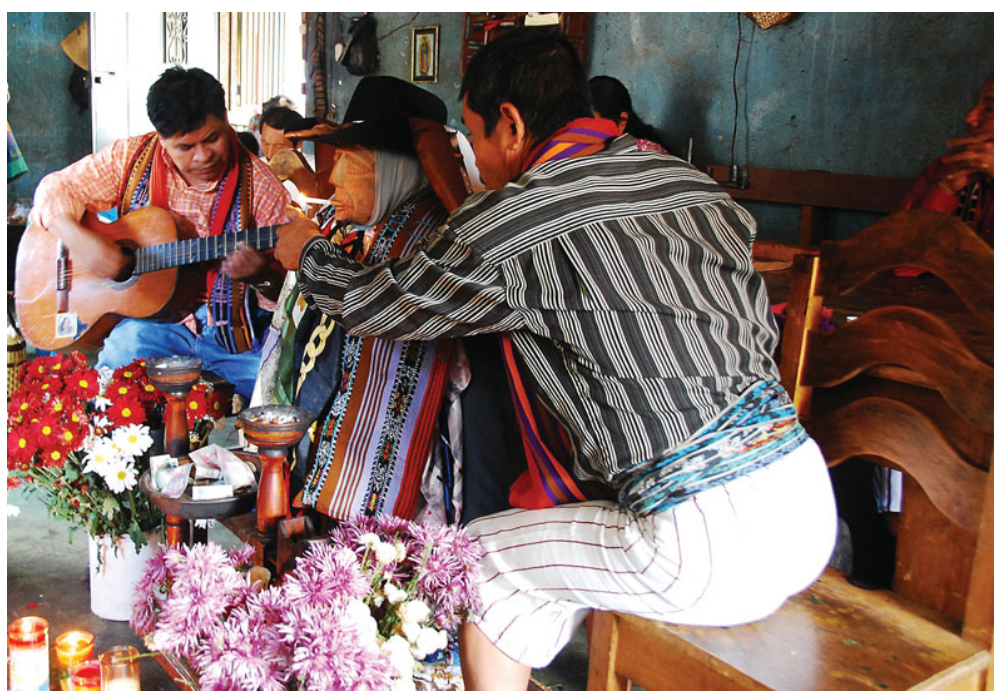

Figure 3. The Rilaj Mam is offered a cigarette. Photo: Allen Christenson

may not always be as distinct as their antagonism on the Rabbit Vase suggests. They trade off dominion over the underworld from day to night; they wear jaguar pelts and hats of predator birds; they preside over major times of transition. Bolon Yokte's unique attributes are his solar features, his Seven-Centipede-Eagle weapons and insignia, and a rope around his neck. His program of war and sacrifice serves and replenishes that of regeneration and rebirth in a reciprocal relationship, as seen on the Tablet of the Sun.

Thus we acknowledge the authority implicit in vestments and adornments, and have seen that a powerful god can be utterly humiliated when those items are taken. The Classic Maya investiture of Bolon Yokte' and its modern reflections are testimony to an enduring, quintessentially Mayan understanding of balance. While some academics field a dismissive counterpoint to the lightning rod of 2012 and the projections it attracts (Houston 2008), this monument reminds us to honor that balance, as is done in Santiago Atitlán, and as Bahlam Ajaw would have expected of his far-future descendants.

\section{Tortuguero Monument Six: the full text in Classic Ch'olan and English}

N.B. Gregorian Calendar correspondences use the 584283 correlation constant.

(E1-F3)chihil akan, kakaw,

chi:t-k'uh

Bahlam Ajaw, K'uhul Ba:k Ajaw.

(E4-F5) waxak k'i:n, buluch winikiji:y, buluch ha'abi:y, ju:n winikha'abi:y siyaji:y,

(E6-F8) alay ta Jun Ok, U:x Bix Ohl chumwani ta ajawlel

Bahlam Ajaw.

(E9-F9) waklaju:n k'i:n, ho' winikiji:y chumwani:y,

(E10-E12) i ehmey unah uto:k'pakal; nuhp-te'aj ta Ayi:n.

i hayi Xam? Aj U:x Te' K'uh

U:xlaju:n Kimi, Chanlaju:n Kase:w.
... the pulque-like God $\mathrm{A}^{\prime}$ and deified cacao, companion gods (of)

Bahlam Ajaw, Holy Ba:k Lord.

Eight days, eleven-score days, eleven Tun and one $\mathrm{K}^{\prime}$ atun after he was born,

here on 1 Ok, 3 Kumk'u (Feb. 7, 644)

he was seated in rulership

Bahlam Ajaw.

Sixteen days and five-score days

after he was seated,

then descended the first of his flints and shields; lances

joined at Ayi:n;

then collapsed Xam? He of U:x Te' K'uh

it is $13 \mathrm{Kimi}, 14$ Sek. (Jun. 2, 644) 
(F12) chan k'i:n, lajcha' winikiji:y:

(E13-E16) alay Laju:n Ok, Waxaklaju:n K'anasi:y; i ch'ahk'aj ?? .

waklaju:n k'i:n, bolon winikiji:y, chan ha'abi:y; (F16-H1) alay Waxak Kimi, Bolon Mol;

i ch'ahk'aj Yomo:p.

(G2-H3) waxak k'i:n, wuk winikiji:y: alay U:xlaju:n Hix, Wuklaju:n Muwa:n; (G4-H5) hayi:y uto:k' [u]pakal U:x Bahlam, Joy Chan Ajaw;

(G6-G9) nahbaj ch'ich', witzaj jol;

bolon ipnaj usak ba:k [y]ik'il

tu yax chan

Bahlam Ajaw, K'uhul Ba:k Ajaw.

(H9-G11) ju:n k'i:n, waklaju:n winik, u:x ha'ab chumwani:y ta ajawlel,

(H11-G13) i k'ahxi t'a:n

Buluch Chuwen, Chan Muwa:n;

(H13-G14) buluch k'i:n, ju:n winikiji:y cha'an Wak Ajaw, U:xlaju:n Mak, wi'il ho'tu:n.

(H14-H16) wak k'i:n, ju:n winikiji:y, bolonlaju:n ha'abi:y, chanlaju:n winikha'abi:y, (G17-J2) k'ahxi:y t'aan.

Buluch Chikchan U:xlaju:n Muwa:n. uhti:y tahn ha' Ba:ki:l.

(I3-J5) waxak k'i:n, ho' winikiji:y, ho' ha'abi:y, ju:n winikha'abi:y chumwani:y ta ajawlel

Bahlam Ajaw,

(I6-I8) i ele-na:haj;

Bolon Etz'nab; Nahnal uti' hu'un;

Wak K'anasi:y.

(J8-I11)

waxaklaju:n k'i:n, waxak winikiji:y, jun ha'abi:y, cha'an Chan Ajaw U:xlaju:n Mol,

wi'il ho'tu:n alay.

(J11-I16) i ekwani

Wak Ha'ab Na:h, Wak Mul Baj-Le:muk'uhul k'aba'

u ?? ??

[Bahlam Ajaw] K'uhul Ba:ki:l Ajaw.

(J16-K1) uba:h uchi:t-ch'ab Ix Wan K'oj,

Ix Ba:ki:l Ajaw.

(L1-K3) unich ukotz'o:m

Ihk' Muy Muwa:n,

K'uhul Ba:k Ajaw.

(L3-K4) ha'i pikul ajaw joyni:y.

(L4-K6) bolon ipni:y

$\mathrm{k}^{\prime}$ an nal ajaw,

? -(Vy) (Square-nosed Beast), sak ba:k ik'.

(L6-K8) yitaj u k'uhil

Ihk' K'ahk'-Ti' Hix, Yax Su:tz'.

(L8-L10) ha'ax ajes yohl waxak kok Baklib, chan ehmach (K11-K12) utzolow yax tzutzpik Yax Pet Kabnal.
Four days and twelve-score days: here is $10 \mathrm{Ok}, 18 \mathrm{~K}^{\prime}$ ayab; (Feb. 1, 645) then was chopped??.

Sixteen days, nine-score days and four Tun; here is $8 \mathrm{Kimi}, 9 \mathrm{Mol}$; (Jul. 26, 649) then was chopped Yomo:p.

Eight days and seven-score days:

here is 13 Hix, 17 Muwa:n; (Dec. 21, 649)

collapsed his flints and his shields, U:x Bahlam, Lord of Joy Chan;

blood became a lake; skulls became a mountain;

nine times were strengthened his force and breath in his first heaven

Bahlam Ajaw, Holy Ba:k Lord.

One day, seventeen-score days and three Tun after he was seated in rulership,

then was bound the word

on 11 Chuwen 4 Muwa:n; (Dec. 9, 647)

Eleven days and one score of days ago,

Made was 6 Ajaw 13 Mak, (Nov. 8, 647)

it was the last Hotun.

Six days, one score of days,

nineteen Tun and fourteen $\mathrm{K}^{\prime}$ atun ago

was bound the word.

It was 11 Chikchan, 13 Muwa:n; (Feb. 27, 353)

it happened in the plaza of Ba:ki:l.

Eight days, five-score days,

five Tun and one $\mathrm{K}^{\prime}$ atun

after he was seated in rulership

Bahlam Ajaw,

then was done a fire-rite in the house;

it is 9 Etz'nab; Nahnal is the margin of the book;

it is $6 \mathrm{~K}^{\prime}$ ayab. (Jan. 14, 669)

Eighteen days, eight-score days and one Tun

Made was 4 Ajaw, $13 \mathrm{Mol}$, (Jul. 26, 667)

it was the last Hotun.

Here is placed

[the] Six-Tun House, [the] Six Cached Hammer-Celtsthe holy name of his

?? ??

[Bahlam Ajaw] Holy Ba:ki:l Lord.

He is the person of her co-creation

Lady Wan K'oj,

Lady Ba:ki:l Lord.

He is the flower of his winder [-serpent]

Ihk' Mu:y Muwa:n

Holy Ba:k Lord.

That one, many lords did he invest.

Nine times were strengthened

the Precious Maize Lord,

the primordial Square-nosed Beast,

the force and breath.

They have authorized this, their gods

Black Fire-Mouth Jaguar and Blue-Green Bat.

These indeed awaken the hearts of

eight turtle Bakabs? and the four raccoons

who set in order the first Kalabtun

at the First Round Earth-place. 
(L12-K16) ma' ?? ??

?? Bahlam Ajaw?.

k'an tu:n uti' uyon.

(L16-M2) wuk k'i:n, wuk winikiji:y, mih ha'abi:y, waxak winikha'abi:y, uhti:y Waxak Chuwen, Bolon Mak;

(N2-N4) ekwani:y nah k'anhal upibna:h Ahkal K'uk'.

(M5-P1) cha' k'i:n, bolon winikij, u:x ha'ab, waxak winikha'ab, u:x pik,

(O2-P3) tzuhtzjo:m uyu:xlaju:n pik

Chan Ajaw, U:x Uni:w.

(O4-P5) uhto:m il

ye:n Bolon Yokte'

ta chak joyaj.

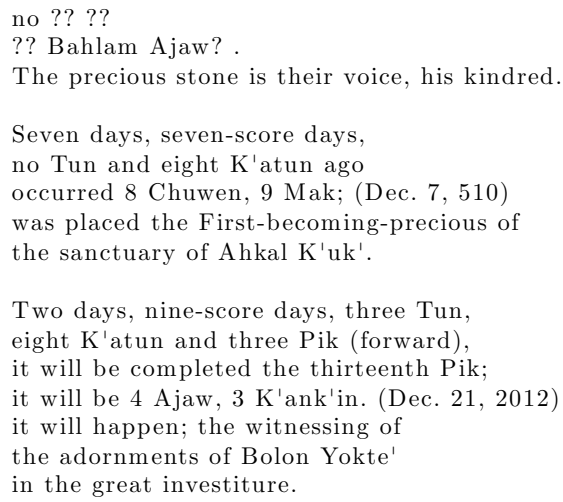

\section{References}

Arellano Hernández, A. 2006, Tortuguero: una Historia Rescatada, Universidad Nacional Autónoma de México, Mexico City.

Boot, E. n.d., At the Court of Itzam Nah Yax Kokaj Mut. Unpublished Manuscript in the possession of the author.

Calleman, C. J. 2009, The Tortuguero Monument 6 and the Mayan End Date. http://www.calleman.com/content/articles/the_tortuguero\%20 monument.htm.

Christenson, A. 2001, Art and Society in a Highland Maya Community: the Altarpiece of Santiago Atitlán, University of Texas Press, Austin.

Eberl, M. \& Prager, C. 2005, B'olon Yokte' K'uh: Maya conceptions of war, conflict, and the underworld. In P. Eeckhout \& G. Le Fort (eds), Wars and Conflicts in Prehispanic Mesoamer$i c a$ and the Andes, BAR International Series, Archaeopress, Oxford, pp. 28-36.

Grofe, M. 2009, The Name of God L: B' olon Yokte' $K^{\prime}$ uh? Wayeb Notes 30, European Association of Mayanists.

Gronemeyer, S. 2004, Tortuguero, Tabasco, Mexiko: Geschichte einer klassischen Maya-Stadt, dargestellt an ihren Inschriften (2 vols). Master's Thesis, Institut für Altamerikanistik und Ethnologie, Rheinische Friedrich-Wilhelms-Universität, Bonn.

Gronemeyer, S. 2006, The Maya site of Tortuguero: its History and Inscriptions, Acta Mesoamericana vol. 17, Verlag Anton Saurwein, Markt Schwaben.

Gronemeyer, S. \& MacLeod, B. 2010. What Could Happen in 2012: a Re-Analysis of the 13Bak'tun Prophecy of Tortuguero Monument 6, Wayeb Notes 34, European Association of Mayanists.

Houston, S. 2008, What Will Not Happen in 2012. Maya Decipherment: a Weblog on the Ancient Maya Script. http://decipherment.wordpress.com/ 2008/12/20/what-will-not-happen-in-2012/.

Houston, S. \& Stuart, D. 1996, Of gods, glyphs, and kings: divinity and rulership among the Classic Maya. Antiquity 70, 289-312.

Mathews, P. 1975, Tortuguero Monument 6. Unpublished manuscript in the possession of the author.

Riese, B. 1978, La inscripción del Monumento 6 de Tortuguero. Estudios de Cultura Maya 11, $187-198$.

Riese, B. 1980, Die Inschriften von Tortuguero, Tabasco. Materialien der Hamburger Maya Inschriften Dokumentation, no. 5, Universität Hamburg, Hamburg.

Van Stone, M. 2010, 2012: Science and Prophecy of the Ancient Maya, Tlacaelel Press, San Diego.

Zender, M. \& Guenter, S. 2003, The names of the Lords of Xib'alb'a in the Maya hieroglyphic script. In R. von Hanffstengel \& C. Tercero Vasconcelos (eds), Eduard y Caecelie Seler: Sistematicización de los Estudios Americanistas y sus Repercusiones, Ediciones y Gráficos Eón, Mexico City. 